\title{
Likwidacja Zbiornicy Księgozbiorów Zabezpieczonych w Poznaniu ${ }^{1}$
}

\begin{abstract}
Streszczenie. Po II wojnie światowej, 1 lutego 1947 roku, w Polsce powstało siedem zbiornic-segregatorni. Jedną z nich była Zbiornica Księgozbiorów Zabezpieczonych w Poznaniu. Zgromadziła ona liczne zbiory zwłaszcza z terenów Wielkopolski, Dolnego Śląska oraz Pomorza Zachodniego. Woluminy przekazywane były, za zgodą władz państwowych, przede wszystkim instytucjom naukowym. Formalna likwidacja Zbiornicy nastąpiła 31 grudnia 1949 roku. Jej zasoby, liczące około 286000 tomów, przejęła Biblioteka Uniwersytecka w Poznaniu, która kontynuowała prace związane z segregacja, repartycją oraz zwożeniem książek z terenu. W 1953 roku w magazynach byłej poznańskiej Zbiornicy pozostawało ponad 250000 tomów, głównie poniemieckiej proweniencji. Dzieła te zostały przekazane Zbiornicy Księgozbiorów Zabezpieczonych w Katowicach oraz Bibliotece Uniwersyteckiej w Poznaniu. Część książek, uznanych za zbędne, przeznaczono na makulaturę.
\end{abstract}

SŁowa kluczowe: Polska, Poznań, biblioteki, zbiornica książek, ochrona zbiorów, XX wiek.

Władze państwowe 1 lutego 1947 roku utworzyły na terenie kraju siedem zbiornic-sortowni: w Gdańsku, Katowicach, Krakowie, Poznaniu, Szczecinie, Toruniu oraz we Wrocławiu. Powstanie instytucji, podlegających bezpośrednio Ministerstwu Oświaty, zapoczątkowało drugi etap związany z powojenną ochroną zbiorów bibliotecznych. Pierwszy rozpoczął się w 1944 roku na skrawku ziem polskich wolnych od okupanta niemieckiego i trwał do końca 1946 roku. Zgromadzone w ogromnych ilościach księgozbiory, tzw. opuszczone i porzucone, poddawano segregacji i repartycji. Władze państwowe uznały, iż mogą one w części zrekompensować straty okresu II wojny światowej oraz przyczynić się do odbudowy bibliotek w Polsce. Woluminy trafiały przede wszystkim

1 Projekt został sfinansowany ze środków Narodowego Centrum Nauki przyznanych na podstawie decyzji numer DEC-2011/03/B/HS2/05446. 
do instytucji naukowych. Zbiornice formalnie funkcjonowały, z wyjątkiem jednej w Katowicach ${ }^{2}$, do końca 1949 roku, tj. do czasu zakończenia drugiego etapu ${ }^{3}$. Faktycznie jednak działały jeszcze na początku lat 50. Celem artykułu jest przedstawienie problemu likwidacji Zbiornicy w Poznaniu oraz losów zgromadzonych w niej dzieł. W pracy wykorzystano przede wszystkim materiały źródłowe przechowywane w Archiwum Biblioteki Uniwersyteckiej w Poznaniu oraz w Archiwum Akt Nowych w Warszawie.

Zbiornica Księgozbiorów Zabezpieczonych w Poznaniu gromadziła książki, które zostały zabezpieczone już wcześniej, tj. poczynając od 1945 roku, przez okręgowego kierownika bibliotecznego, a zarazem dyrektora Biblioteki Uniwersyteckiej w Poznaniu, Aleksandra Birkenmaje$\mathrm{ra}^{4}$. Część dzieł została przekazana przez Kuratorium Okręgu Szkolnego Poznańskiego i inspektoraty szkolne. W pierwszym okresie powojennej ochrony zbiorów bibliotecznych należało przede wszystkim ocalić tomy przed fizycznym zniszczeniem. Nie starczało wówczas czasu na dokładne przeliczenie zabezpieczonego materiału oraz repartycję. Sytuacja ta miała się zmienić po utworzeniu zbiornic-segregatorni. Jednak $\mathrm{w}$ pracy nadal występowały trudności. Przeszkody wynikały z nielicznego personelu, w stosunku do ogromu potrzeb, zbyt skromnych środków finansowych przyznawanych na prowadzenie czynności czy dotkliwego braku pomieszczeń do składowania książek. Starania Birkenmajera o przydział pomieszczeń w poznańskim Zamku na magazyn-sortownię nie przyniosły pozytywnego rezultatu.

Pomimo ogromnych zniszczeń okresu II wojny światowej przetrwały liczne księgozbiory, które w 1947 roku, oraz w okresie późniejszym, tj. do zakończenia działalności poznańskiej Zbiornicy, nadal zwożono z terenu. Instytucja w kilku magazynach, w tym również w budynku Biblioteki, zgromadziła zarówno cenne dzieła, jak i materiał uznany za zbędny, posiadający wartość makulatury (np. literaturę propagandową nazistowską). Podczas transportowania dzieł często nie starczało bowiem czasu na dokładną selekcje zwożonego materiału.

2 Zbiornica Księgozbiorów Zabezpieczonych w Katowicach działała do 31 grudnia 1955 roku. W latach 50. podlegała Ministerstwu Kultury i Sztuki.

3 W latach 1950-1955 trwał trzeci etap powojennej ochrony zbiorów bibliotecznych, związany z działalnością Zbiornicy Księgozbiorów Zabezpieczonych w Katowicach. Por. R. Nowicki, Powojenna ochrona zbiorów bibliotecznych w Polsce w latach 1944-1955. Wybór źródet, Bydgoszcz 2013, s. 12.

4 Zob. R. Nowicki, Działalność Aleksandra Birkenmajera na rzecz powojennej ochrony zbiorów bibliotecznych. Ziemie zachodniej i pótnocnej Polski w latach 1945-1947, Poznań 2006. 
Zbiornica funkcjonowała przy Bibliotece Uniwersyteckiej w Poznaniu ${ }^{5}$. Posiadała jedną filię w Krotoszynie, która nie odegrała jednak większej roli. Pierwszym kierownikiem został Birkenmajer, a po jego odejściu do Krakowa, w połowie 1947 roku, Bolesław Świderski' ${ }^{6}$. Filią w Krotoszynie kierowała od 1 maja 1947 roku do 31 sierpnia 1948 roku Romana Szcześniakowa. Personel instytucji składał się głównie z pracowników Biblioteki Uniwersyteckiej. Zbiornica dysponowała materiałem przywiezionym przede wszystkim z obszaru Wielkopolski, a także częściowo z terenu Dolnego Śląska i Pomorza Zachodniego. Znaczna liczba dzieł pochodziła z magazynów utworzonych przez Niemców podczas II wojny światowej w samym Poznaniu. Zamienili oni trzy kościoły, św. Michała, św. Małgorzaty oraz św. Stanisława, na składnice. Do największej, znajdującej się w świątyni św. Michała, okupant podczas wojny zwiózł w sumie około 3000000 woluminów, w tym m.in. z terenów centralnej Polski. Z ogromnego zasobu skomasowanych dzieł, w wyniku zniszczenia pod koniec wojny górnego kościoła, przetrwało kilkaset tysięcy tomów. Zbiornica dysponowała również dziełami pochodzącymi z innych państw, zrabowanymi i przewiezionymi przez Niemców. Wśród zgromadzonych woluminów znajdowały się liczne poniemieckiej proweniencji, przetransportowane zwłaszcza z Pomorza Zachodniego i Dolnego Śląska. Pod koniec 1947 roku Zbiornica posiadała ogółem 451000 tomów zabezpieczonych (tab. 1). Liczba ta z upływem czasu malała i wynosiła w listopadzie 1949 roku około 350000 tomów nieopracowanych ${ }^{7}$. O ich przydziale decydowało Ministerstwo Oświaty. Na podkreślenie zasługuje fakt, iż w poznańskiej Zbiornicy, do połowy 1949 roku, książki oddawane były prawowitym właścicielom, po stwierdzeniu proweniencji, ,za milczącą zgodą" naczelnego dyrektora bibliotek Ministerstwa Oświaty Józefa Grycza oraz w wyniku wewnętrznego zarządzenia Aleksandra Birkenmajera ${ }^{8}$. Później przekazywanie tomów osobom prywatnym było możliwe wyłącznie po uzyskaniu aprobaty Ministerstwa Oświaty. Jednak liczba prawowitych właścicieli, którzy wówczas otrzymali stosowną

5 Ibidem, s. 201-207.

6 A. Jazdon, Bolestaw Świderski jako kierownik Zbiornicy Księgozbiorów Zabezpieczonych w Poznaniu - przyczynek do poznańskiego okresu działalności, w: Bibliotekarstwo wedtug Bolestawa Świderskiego - Myśli, praktyka, dydaktyka. Księga Pamiatkowa, red. S. Kurek-Kokocińska, Łódź 2009, s. 35-55.

7 Archiwum Biblioteki Uniwersyteckiej w Poznaniu (dalej: ABUP), Biblioteka Uniwersytecka. Uporzadkowanie księgozbioru 25 IV 1949-31 III 1953, sygn. 554, k. 48 B. Szulc-Golska, Sprawozdanie z czynności zwiazanych z porzadkowaniem zbiorów zabezpieczonych za miesiac listopad 1949 r., Poznań, 7 grudnia 1949 roku.

8 R. Nowicki, Dziatalność Aleksandra Birkenmajera..., s. 288-289. 
zgodę, drastycznie zmalała w porównaniu z okresem wcześniejszym. W wyjątkowych sytuacjach ministerstwo przyzwalało na czasowe przekazanie dzieł innym osobom. Do nich należał m.in. Arkady Fiedler, który w maju 1950 roku otrzymał informację o następującej treści: „Ministerstwo Oświaty komunikuje, że osobom prywatnym nie przydziela się żadnych książek. Ministerstwo jednak chcąc przyjść z pomocą Obywatelowi, wyraża zgodę na wypożyczenie ze zbiorów zabezpieczonych w Poznaniu książek, potrzebnych Obywatelowi do Jego pracy literackiej"9.

Tabela 1. Liczba woluminów w Zbiornicy Księgozbiorów Zabezpieczonych w Poznaniu pod koniec 1947 roku

\begin{tabular}{|l|c|}
\hline \multicolumn{1}{|c|}{ Magazyn } & Woluminy \\
\hline Collegium Philosophicum & 27000 \\
\hline Collegium Minus & 4000 \\
\hline Collegium Medicum & 100000 \\
\hline Biblioteka Uniwersytecka & 150000 \\
\hline Składnica przy ul. Kantaka & 80000 \\
\hline Kościół św. Michała w Poznaniu & 50000 \\
\hline Filia Zbiornicy w Krotoszynie & 40000 \\
\hline Razem & 451000 \\
\hline
\end{tabular}

Źródło: Biblioteka Uniwersytecka w Poznaniu, Sprawozdanie Biblioteki Uniwersyteckiej w Poznaniu za rok 1947, Poznań 1948, s. 81.

W sprawozdaniu Bolesława Świderskiego z działalności Zbiornicy w latach 1945-1950 zawarte są interesujące dane związane z rezultatami pracy instytucji ${ }^{10}$. Zbiornica, jak wspomniano, powstała 1 lutego 1947 roku. Bolesław Świderski celowo i świadomie nawiązał do czynności podjętych dwa lata wcześniej z powodu kontynuacji przez placówkę rozpoczętych wówczas prac i przejęcia części zabezpieczonych książek. Na podstawie danych zawartych w Sprawozdaniu należy stwierdzić, iż ogółem zabezpieczono i zwieziono ponad 1200000 tomów $^{11}$. Dzieła, w wyniku przydziałów Ministerstwa Oświaty, powiększyły zbiory Biblioteki

9 ABUP, Biblioteka Uniwersytecka. Referat Zabezpieczania i Segregacji Księozbiorów. Zbiornica - księozbiory zabezpieczone 1949-1951, sygn. 555, k. 137 - Ministerstwo Oświaty do Biblioteki Uniwersyteckiej w Poznaniu, Warszawa, 23 maja 1950 roku.

${ }^{10}$ Archiwum Akt Nowych w Warszawie (dalej: AAN), Ministerstwo Oświaty. Naczelna Dyrekcja Bibliotek. Wydział Bibliotek Naukowych, sygn. 6953, k. 2-14 - Bolesław Świderski, Sprawozdanie z działalności Zbiornicy Księgozbiorów Zabezpieczonych w Poznaniu. Lata 1945-1950, Poznań, 23 marca 1950 roku.

${ }^{11}$ Ibidem, k. 8. 
Uniwersyteckiej w Poznaniu, a także innych instytucji $\mathrm{w}$ mieście oraz na terenie $\mathrm{kraju}^{12}$. W ramach repartycji przekazano około 945000 tomów 280 instytucjom i kilkuset osobom prywatnym ${ }^{13}$. Stosunkowo skromny personel Biblioteki nie był jednak w stanie dokonać szybkiej segregacji wszystkich dzieł. Ponadto wiele książek zabezpieczonych posiadały nadal różne instytucje, które zgłaszały chęć ich przekazania. Sygnały docierały nie tylko z Wielkopolski, ale też z innych regionów kraju. Przykładowo prezes Sądu Apelacyjnego w Katowicach Eugeniusz Kral pod koniec grudnia 1949 roku skierował zapytanie, w jaki sposób Zbiornica Księgozbiorów Zabezpieczonych w Poznaniu odbierze 118 książek propagandowych hitlerowskich, znalezionych $w$ bibliotece Sądu ${ }^{14}$. W tym przypadku kompetencje do przejęcia tomów posiadała Zbiornica Księgozbiorów Zabezpieczonych w Katowicach.

Interesujące informacje dotyczące prowadzonych prac zawierają m.in. sprawozdania z dwóch ostatnich miesięcy działalności Zbiornicy. W listopadzie 1949 roku przejęto z Liceum Ogólnokształcącego w Gorzowie Wielkopolskim poniemiecki księgozbiór liczący 5000 tomów ${ }^{15}$. Dokonano segregacji (w magazynie Collegium Philosophicum) około 9000 tomów. W ramach repartycji przekazano:

- Bibliotece Narodowej w Warszawie - 264 woluminy rękopisów pochodzące z Seminarium Duchownego we Włocławku, 1153 mapy, 3188 tomów starych druków ze Wschowy oraz 104 tomy książek,

- Seminarium Historycznemu Uniwersytetu Poznańskiego - 580 tomów,

- Instytutowi Zachodniemu w Poznaniu - 78 tomów,

- Bibliotece Uniwersyteckiej w Poznaniu - 13800 tomów oraz 9 map,

- J. Dąbrowskiemu - 127 tomów.

Ogółem przekazano w listopadzie 1949 roku 264 woluminy rękopisów, 17877 tomów książek oraz 1162 mapy. Miesiąc później przejęto od

${ }^{12}$ Zob. M. Głowacka-Helak, Działalność Biblioteki Uniwersyteckiej w Poznaniu nad zagospodarowaniem księgozbiorów porzuconych i opuszczonych. Lata 1947-1950, „Biblioteka" 2003, nr 7 (16), s. 69-78.

13 AAN, Ministerstwo Oświaty. Naczelna Dyrekcja Bibliotek. Wydział Bibliotek Naukowych, sygn. 6953, k. 9 - Bolesław Świderski, Sprawozdanie z działalności Zbiornicy Księgozbiorów Zabezpieczonych w Poznaniu. Lata 1945-1950, Poznań, 23 marca 1950 roku.

14 ABUP, Biblioteka Uniwersytecka. Referat Zabezpieczania i Segregacji Ksiegozbiorów. Zbiornica - księgozbiory zabezpieczone 1949-1951, sygn. 555, k. 6 - Eugeniusz Kral do Zbiornicy Księgozbiorów Zabezpieczonych w Poznaniu, Katowice, 21 grudnia 1949 roku.

15 AAN, Ministerstwo Oświaty. Naczelna Dyrekcja Bibliotek. Wydział Bibliotek Naukowych, sygn. 6954, k. 78 - Bolesław Świderski, Sprawozdanie z działalności w miesiącu listopadzie 1949 r. 
Seminarium Filologii Germańskiej Uniwersytetu Poznańskiego 469 dzieł ${ }^{16}$. Dokonano segregacji 10000 woluminów (w Collegium Philosophicum i składnicy przy ul. Kantaka). Przekazano:

- Zakładowi Historii Filozofii Medycyny Uniwersytetu Poznańskiego - 120 tomów i 60 zeszytów czasopism,

- Seminarium Historycznemu Uniwersytetu Poznańskiego - 1355 tomów,

- do Warszawy (Centralne Biuro Wystaw) - 72 tomy,

- Bibliotece Ministerstwa Kultury i Sztuki w Warszawie - 83 tomy,

- Państwowemu Muzeum Kultury Ludowej w Młocinach - 1529 tomów,

- Bibliotece Towarzystwa Przyjaciół Nauk w Poznaniu - 46 map i 5 atlasów,

- Bibliotece Uniwersyteckiej w Poznaniu - około 35000 tomów.

Z powyższych danych wynika, iż praca w Zbiornicy była daleka od zakończenia. Segregacji nadal wymagały liczne tomy.

Formalna likwidacja Instytucji nastąpiła 31 grudnia 1949 roku. Naczelny Dyrektor Bibliotek Ministerstwa Oświaty Józef Skrzypek jesienią 1949 roku skierował pismo do Biblioteki Uniwersyteckiej w Poznaniu w sprawie przejęcia z dniem 1 stycznia 1950 roku zasobów Zbiornicy Księgozbiorów Zabezpieczonych i kontynuacji jej działalności w ramach prac Biblioteki ${ }^{17}$. Polecił zatrudnić Bolesława Swiderskiego do 31 stycznia 1950 roku, tj. do czasu rozwiązania przez Ministerstwo Oświaty umowy zawartej z nim jako kierownikiem Zbiornicy. Jednocześnie Ministerstwo Oświaty zawiadomiło o wstrzymaniu od 1 stycznia tego roku przekazywania kredytów dla Zbiornicy, z wyjątkiem wynagrodzenia za styczeń dla Bolesława Świderskiego. Decyzja ta niezmiernie utrudniła dalsze transportowanie księgozbiorów z terenu, część oczekiwała na zabranie nawet od 1945 roku. Nie posiadały one jednak tak wysokiej wartości naukowej jak zwiezione wcześniej.

Przekazane zasoby nadal stanowiły depozyt Ministerstwa Oświaty, a następnie Ministerstwa Kultury i Sztuki. Biblioteka Uniwersytecka posiadała prawo pierwszeństwa wyboru woluminów i włączenia ich do własnego zbioru. Wykazy wysegregowanych książek wymagały akceptacji Naczelnej Dyrekcji Bibliotek Ministerstwa Oświaty, później natomiast

${ }^{16}$ AAN, Ministerstwo Oświaty. Naczelna Dyrekcja Bibliotek. Wydział Bibliotek Naukowych, sygn. 6954, k. 81 - Bolesław Świderski, Sprawozdanie z działalności w miesiącu grudniu 1949 r.

17 ABUP, Biblioteka Uniwersytecka. Referat Zabezpieczania i Segregacji Księgozbiorów. Zbiornica - księgozbiory zabezpieczone 1949-1951, sygn. 555, k. 1 - Józef Skrzypek do Biblioteki Uniwersyteckiej w Poznaniu, Warszawa, 27 października 1949 roku. 
Centralnego Zarządu Bibliotek Ministerstwa Kultury i Sztuki. Także wnioski o przydziały tomów dla innych instytucji winny były uzyskać aprobatę ministerstwa. W okresie stalinizacji kraju i wprowadzania wzorów radzieckich $\mathrm{w}$ polskich bibliotekach przekazywanie dzieł natrafiało na przeszkody. Przykładowo 23 lipca 1952 roku Centralny Zarząd Bibliotek Ministerstwa Kultury i Sztuki zakwestionował część pozycji figurujących w spisie dzieł, które miały być ofiarowane parafii ewangelickiej w Koninie, ze względu na ich rzekomą wartość polityczno-wychowawczą: „Książki przekazane winny dotyczyć wyłącznie zagadnień ściśle teologicznych. Wyłączyć należy szereg książek związanych wprawdzie tematycznie ze sprawami kościelnymi, ale poruszających zagadnienia społeczne i polityczne w duchu antymarksistowskim"18.

Wiele dzieł znajdowało się nadal w posiadaniu władz szkolnych. Sytuacja ta wynikała z faktu nałożenia obowiązku, na mocy okólnika kierownika Resortu Oświaty Stanisława Skrzeszewskiego z 29 listopada 1944 roku $^{19}$, ochrony zbiorów bibliotecznych przez władze szkolne I i II instancji, tj. inspektoraty oraz kuratoria szkolne. Pomimo upływu kilku lat, licząc od daty ogłoszenia zarządzenia, nadal magazynowano liczne woluminy. Kierownik Referatu Bibliotek Kuratorium Okręgu Szkolnego Poznańskiego Franciszek Mierniczak skierował do Ministerstwa Oświaty wniosek o zlikwidowanie magazynu książek poniemieckich znajdujących się przy kuratorium. W połowie stycznia 1950 roku naczelny dyrektor bibliotek Józef Skrzypek upoważnił Bibliotekę Uniwersytecką w Poznaniu do zajęcia się tą sprawą ${ }^{20}$. Ponadto ministerstwo postanowiło, iż pozycje nieprzedstawiające żadnej wartości zabytkowej ani użytkowej będzie można komisyjnie uznać za makulaturę. Informacje docierały również z terenu. Na przykład inspektor szkolny w Środzie Wielkopolskiej w kwietniu 1950 roku zawiadamiał o posiadaniu $0,5 \mathrm{~m}^{3}$ książek poniemieckich, przede wszystkim z zakresu pedagogiki ${ }^{21}$. Większa liczba dzieł, około $3 \mathrm{~m}^{3}$ (zabezpieczonych jeszcze w 1945 roku), znajdowała się w Inspektoracie Szkolnym

18 ABUP, Biblioteka Uniwersytecka. Uporzadkowanie księgozbioru 25 IV 1949-31 III 1953, sygn. 554, k. 321 - Wanda Michalska do Biblioteki Uniwersyteckiej w Poznaniu, Warszawa, 23 lipca 1952 roku.

19 „Dziennik Urzędowy Resortu Oświaty” 1944, nr 1-4, poz. 32.

${ }^{20}$ ABUP, Biblioteka Uniwersytecka. Referat Zabezpieczania i Segregacji Księozbiorów. Zbiornica - księgozbiory zabezpieczone 1949-1951, sygn. 555, k. 18 - Józef Skrzypek do Biblioteki Uniwersyteckiej w Poznaniu, Warszawa, 17 stycznia 1950 roku.

${ }^{21}$ ABUP, Biblioteka Uniwersytecka. Referat Zabezpieczania i Segregacji Księozbiorów. Zbiornica - księgozbiory zabezpieczone 1949-1951, sygn. 555, k. 112 - Edward Dobraszak do Biblioteki Uniwersyteckiej w Poznaniu, Środa Wielkopolska, 22 kwietnia 1950 roku. 
w Strzelcach Krajeńskich ${ }^{22}$. W Kościanie, w budynku Prezydium Powiatowej Rady Narodowej zmagazynowano około 4000 tomów książek poniemieckich, zebranych $\mathrm{w}$ szkołach powiatu kościańskiego. Większość $\mathrm{z}$ nich znajdowała się $\mathrm{w}$ wilgotnych piwnicach ${ }^{23}$.

Ile dzieł ze zlikwidowanej Zbiornicy trafiło do Biblioteki? Liczba ta została dość precyzyjnie określona. Dyrektor Biblioteki Uniwersyteckiej w Poznaniu Stefan Vrtel-Wierczyński przesłał do Ministerstwa Oświaty na początku 1950 roku protokół z przejęcia księgozbiorów w Poznaniu ${ }^{24}$. W dokumencie tym Bolesław Świderski, występujący nadal jako kierownik Zbiornicy, przekazał pięć składnic książek, w których znajdowało się w sumie około 286000 tomów (tab. 2).

Tabela 2. Liczba tomów przejętych z poznańskiej Zbiornicy Księgozbiorów Zabezpieczonych przez Bibliotekę Uniwersytecką w Poznaniu 27 lutego 1950 roku

\begin{tabular}{|l|c|c|}
\hline \multicolumn{1}{|c|}{ Nazwa składnicy } & Liczba tomów & Uwagi \\
\hline Collegium Philosophicum przy ul. Matejki & 132000 & \\
\hline $\begin{array}{l}\text { W Gmachu Biblioteki Uniwersyteckiej } \\
\text { przy ul. Ratajczaka }\end{array}$ & 70000 & \\
\hline Collegium Marianum przy ul. Różanej & 44000 & \\
\hline Składnica przy ul. Kantaka & 30000 & \\
\hline Collegium Maius przy ul. Fredry & 10000 & \\
\hline Razem & 286000 & $\begin{array}{l}\text { Ponadto 20 teczek z aktami } \\
\text { Zbiornicy oraz 2 pieczęcie }\end{array}$ \\
\hline
\end{tabular}

Źródło: ABUP, Biblioteka Uniwersytecka. Referat Zabezpieczania i Segregacji Księgozbiorów. Zbiornica - księgozbiory zabezpieczone 1949-1951, sygn. 555, k. 6 - Protokół przekazania składnic książek Bibliotece Uniwersyteckiej w Poznaniu przez Zbiornice Księozbiorów Zabezpieczonych w Poznaniu, Poznań, 27 lutego 1950 roku.

22 ABUP, Biblioteka Uniwersytecka. Referat Zabezpieczania i Segregacji Ksiegozbiorów. Zbiornica - księgozbiory zabezpieczone 1949-1951, sygn. 555, k. 125 - Ludwik Kończal do Biblioteki Uniwersyteckiej Zbiornicy książek zabezpieczonych w Poznaniu, Strzelce, 8 maja 1950 roku.

23 ABUP, Biblioteka Uniwersytecka. Referat Zabezpieczania i Segregacji Ksiegozbiorów. Zbiornica - księgozbiory zabezpieczone 1949-1951, sygn. 555, k. 211 - Adam Krzyżaniak, Sprawozdanie z podróży stużbowej do Kościana, Poznań, 26 lipca 1950 roku.

24 ABUP, Biblioteka Uniwersytecka. Referat Zabezpieczania i Segregacji Ksiegozbiorów. Zbiornica - księgozbiory zabezpieczone 1949-1951, sygn. 555, k. 73 - Stefan Wierczyński do Naczelnej Dyrekcji Bibliotek Ministerstwa Oświaty, [Poznań], 3 marca 1950 roku.

${ }^{25}$ Były to zapewne pieczęcie zawierające napisy:

1) MINISTERSTWO OŚWIATY / ZBIORNICA KSIĘGOZBIORÓW / ZABEZPIECZONYCH / W POZNANIU,

2) KIEROWNIK ZBIORNICY. 
Agendy Zbiornicy Księgozbiorów Zabezpieczonych w Poznaniu zostały zlikwidowane 31 marca 1950 roku $^{26}$. Wobec przejęcia czynności Zbiornicy przez Bibliotekę na początku tego roku dyrektor Stefan Vrtel-Wierczyński skierował pismo do Naczelnej Dyrekcji Bibliotek Ministerstwa Oświaty o przyznanie kredytów na dalsze prowadzenie działań związanych z zabezpieczaniem księgozbiorów. Argumentował to faktem posiadania przez Zbiornicę odrębnego budżetu. Natomiast preliminarz budżetowy Biblioteki na 1950 rok nie przewidywał wydatków na wspomniane cele ${ }^{27}$. Ministerstwo jednak nie posiadało stosownych kredytów ${ }^{28}$. Sytuacja ta niezmiernie utrudniła transportowanie dzieł oraz wyjazdy w teren delegatów.

Inne instytucje posiadające nadal księgozbiory zabezpieczone starały się kierować tego rodzaju materiał do Biblioteki. Przykładowo w marcu 1950 roku dotarło 51 worków z książkami proweniencji poniemieckiej (około 3000 woluminów) przekazanych przez Powiatową Bibliotekę Publiczną w Żninie ${ }^{29}$, a pod koniec września tego roku Okręgowy Urząd Likwidacyjny w Poznaniu przekazał 3115 książek poniemieckich różnej treści, przywiezionych z magazynu Rejonowego Urzędu Likwidacyjnego w Gnieźnie ${ }^{30}$.

Biblioteka Uniwersytecka w Poznaniu w październiku 1950 roku posiadała około 100000 woluminów zabezpieczonych zbiorów nieopracowanych, zgromadzonych w budynku bibliotecznym ${ }^{31}$. Tak więc wzrost tej liczby w okresie kilku miesięcy, tj. od końca lutego tego roku, nastąpił

${ }^{26}$ ABUP, Biblioteka Uniwersytecka. Referat Zabezpieczania i Segregacji Księgozbiorów. Zbiornica - księgozbiory zabezpieczone 1949-1951, sygn. 555, k. 250 - Zofia Kawecka do Prezydium Rady Narodowej w Poznaniu, [Poznań], 23 listopada 1950 roku.

27 ABUP, Biblioteka Uniwersytecka. Referat Zabezpieczania i Segregacji Księgozbiorów. Zbiornica - księgozbiory zabezpieczone 1949-1951, sygn. 555, k. 50 - Stefan Wierczyński do Naczelnej Dyrekcji Bibliotek, Poznań, 13 lutego 1950 roku.

${ }^{28}$ ABUP, Biblioteka Uniwersytecka. Referat Zabezpieczania i Segregacji Ksiegozbiorów. Zbiornica - księgozbiory zabezpieczone 1949-1951, sygn. 555, k. 100 - Józef Skrzypek do Biblioteki Uniwersyteckiej w Poznaniu, Warszawa, 13 kwietnia 1950 roku.

${ }^{29}$ ABUP, Biblioteka Uniwersytecka. Referat Zabezpieczania i Segregacji Księozbiorów. Zbiornica - księgozbiory zabezpieczone 1949-1951, sygn. 555, k. 77 - Bożenna Szulc-Golska do Powiatowej Biblioteki Publicznej w Żninie, Poznań, 16 marca 1950 roku.

${ }^{30}$ ABUP, Biblioteka Uniwersytecka. Referat Zabezpieczania i Segregacji Księgozbiorów. Zbiornica - księgozbiory zabezpieczone 1949-1951, sygn. 555, k. 226 - Okręgowy Urząd Likwidacyjny w Poznaniu do Biblioteki Uniwersyteckiej w Poznaniu, Poznań, 29 września 1950 roku.

${ }^{31}$ ABUP, Biblioteka Uniwersytecka. Referat Zabezpieczania i Segregacji Księgozbiorów. Zbiornica - księgozbiory zabezpieczone 1949-1951, sygn. 555, k. 243 - Bolesław Świderski, Sprawozdanie z czynności związanych z porządkowaniem zbiorów zabezpieczonych za miesiąc październik 1950 r., Poznań, 8 listopada 1950 roku. 
o około 30000 tysięcy $^{32}$. Wszystkie pozycje znajdowały się w skrzyniach lub pozostawały złożone $\mathrm{w}$ stertach. W październiku 1950 roku porządkowało ten zasób 35 pracowników wykwalifikowanych oraz 60 niewykwalifikowanych. Ogółem 95 pracowników przez 26 dni przepracowało 8620 godzin. Przy segregacji książek zatrudnionych było 9 osób, które przepracowały 651 godzin; przy translokacji książek w magazynie, budowie regałów, układaniu książek na półkach - 13 osób (1206 godzin); przy katalogowaniu akcesyjnym (akcesja i szeregowanie kart katalogowych) - 47 osób (4880 godzin); przy kontroli skatalogowanych dzieł 6 osób (229 godzin); przy sprawdzaniu druków z katalogiem głównym Biblioteki - 7 osób (418 godzin); przy katalogowaniu pełnym i inwentaryzowaniu - 9 osób (661 godzin); przy pracach w różnych działach Biblioteki -4 osoby (575 godzin). W okresie jednego miesiąca rozdzielono grupę druków liczącą około 23000 woluminów. Z tego około 2000 woluminów przeznaczono na makulaturę. Skatalogowano akcesyjnie 16770 dzieł (20 898 woluminów). Porządkowanie obejmowało dzieła zabezpieczone złożone w Bibliotece oraz jeden wóz książek zwieziony z magazynu znajdującego się poza budynkiem bibliotecznym. Dotkliwie odczuwano brak miejsca do przechowywania skatalogowanych tomów. Opracowane książki umieszczano na zbudowanych regałach liczących ogółem $120 \mathrm{~m}$ długości. Informacje powyższe świadczą o intensywnych pracach nad porządkowaniem zbiorów, które zostały rozpoczęte we wrześniu 1949 roku. Od tego czasu do końca października 1950 roku skatalogowano akcesyjnie ogółem 173885 dzieł (234 913 woluminów) $)^{33}$.

W magazynach nadal pozostawały liczne dzieła poniemieckie uznane za nieprzydatne dla Biblioteki. Od 1952 roku trwały usilne starania o ich przekazanie do jedynej funkcjonującej Zbiornicy Księgozbiorów Zabezpieczonych w Katowicach, kierowanej przez Franciszka Szymiczka. Między innymi Zofia Kawecka zabiegała o to, by Centralny Zarząd Bibliotek Ministerstwa Kultury i Sztuki wyraził zgodę na przejęcie przez katowicką Zbiornicę książek znajdujących się w składnicy Collegium Philosophicum w Poznaniu, „ze wzgl.[ędu] na ciasnotę i brak miejsca" ${ }^{34}$. W efekcie

${ }^{32}$ Część książek pochodziła z magazynów byłej Zbiornicy, znajdujących się poza budynkiem Biblioteki.

33 ABUP, Biblioteka Uniwersytecka. Referat Zabezpieczania i Segregacji Księgozbiorów. Zbiornica - księgozbiory zabezpieczone 1949-1951, sygn. 555, k. 243 - Bolesław Świderski, Sprawozdanie z czynności zwiąanych z porzadkowaniem zbiorów zabezpieczonych za miesiąc październik 1950 r., Poznań, 8 listopada 1950 roku.

34 ABUP, Biblioteka Uniwersytecka. Uporzadkowanie księgozbioru 25 IV 1949-31 III 1953, sygn. 554, k. 320 - Zofia Kawecka do Centralnego Zarzadu Bibliotek Min. Kultury i Sztuki, Poznań, 26 września 1952 roku. 
podjętych starań rok później, w maju 1953 roku, zapadły ostateczne decyzje co do losów pozostających w magazynach zbiorów pochodzących ze zlikwidowanej poznańskiej Zbiornicy. Na mocy protokołu zdawczo-odbiorczego z 27 maja 1953 roku Zbiornica Księgozbiorów Zabezpieczonych w Katowicach przejęła około 180000 woluminów znajdujących się w magazynach Collegium Philosophicum ${ }^{35}$. Bibliotece Uniwersyteckiej przyznano 71000 woluminów przechowywanych w Collegium Marianum i Collegium Iuridicum oraz pewną liczbę książek z magazynów Collegium Philosophicum. Dzieła uznane za nieprzydatne postanowiono przeznaczyć na makulaturę.

Zbiornica Księgozbiorów Zabezpieczonych w Poznaniu odegrała ważną rolę w powojennej ochronie zbiorów bibliotecznych. W wyniku pracy kierowników, tj. Aleksandra Birkenmajera i Bolesława Świderskiego, ocalone zostały liczne wartościowe księgozbiory, którym w warunkach powojennych groziło zniszczenie. $W$ sumie zabezpieczono w latach 1945-1949 ponad 1200000 tomów. Z analizy zebranych materiałów wynika, że po formalnej likwidacji Zbiornicy, 31 grudnia 1949 roku, jej zmagazynowane zbiory, liczące około 286000 tomów, przejęła Biblioteka Uniwersytecka w Poznaniu. Kontynuowała ona prace związane z segregacją materiału oraz zwożeniem księgozbiorów z terenu. Czynności prowadziła w trudnych warunkach ze względu na brak środków finansowych. Ostatecznie zasoby zlikwidowanej poznańskiej Zbiornicy zostały przejęte w 1953 roku przez Zbiornicę Księgozbiorów Zabezpieczonych w Katowicach oraz Bibliotekę Uniwersytecką w Poznaniu. Część dzieł, uznanych za zbędne, trafiło na przemiał.

\author{
RYSZARD NOWICKI
}

\title{
Removal and clearance of the Storehouse of Secured Libraries in Poznań
}

Aвstract. Soon after WWII, seven storehouses and sorting houses were established in Poland (on February 1st, 1947). One of them was the Storehouse of Secured Libraries in Poznań. The storehouse was used to house numerous "abandoned" book collections, in particular those from the Wielkopolska region, Lower Silesia and Western

35 ABUP, Biblioteka Uniwersytecka. Uporzadkowanie księgozbiorów 25 IV 1949-31 VIII 1953, sygn. 554, k. 353 - Protokót zdawczo-odbiorczy, Poznań, 27 maja [19]53 roku. 
Pomerania. Following formal approval of the authorities, volumes of books were then transferred to various research and scientific institutions. Formally, the Storehouse was liquidated on December 31st, 1949. Its resources, amounting to about 286,000 volumes were taken over by Poznań University Library. The library carried on with the relevant work on segregation, processing, restoration and recovery of books form the designated areas. In 1953, the storehouse still kept more than 250,000 volumes, mainly from former German libraries and book collections. These books were then transferred to the Storehouse of Secured Libraries in Katowice and to Poznań University Library. A number of books deemed to be redundant for the purposes of the libraries involved were subsequently pulped, discarded, or otherwise abused.

Key words: Poland, Poznań, libraries, storehouse of libraries, preservation of collections, 19th c. 